\title{
PETE CRITICAL PEDAGOGIES FOR A NEW MILLENIUM
}

\author{
PEDAGOGIAS CRÍTICAS NA FORMAÇÃO DE PROFESSORES DE EDUCAÇÃO \\ FÍSICA PARA O NOVO MILÊNIO
}

\author{
PEDAGOGÍAS CRÍTICAS EN LA FORMACIÓN DE PROFESORES DE \\ EDUCACIÓN FÍSICA PARA EL NUEVO MILENIUM
}

\author{
Rod Philpot*, Wayne Smith*, Alan Ovens ${ }^{\star}$
}

\section{Keywords:}

Physical education.

Teacher education.
Critical pedagogy.

\begin{abstract}
Socially-critical scholarship and critical pedagogy have become increasingly central to Physical Education Teacher Education (PETE) over the last three decades. The purpose of this paper is to provide a snapshot of the history of the critical project in PETE and an analysis of critical pedagogies in contemporary Western society. In this paper, the accounts of critical pedagogies are classified based on their focus on (a) critical reflection, (b) pedagogies of discomfort and (c) democratic principles, although the authors recognise that in PETE practice these categories overlap and interconnect and do not represent exclusively independent pedagogies. The paper concludes that relationships between PETE teacher educators and PETE students built on trust and care and secondly, connections between PETE teacher educators and the broader physical education teaching community are important as they provide the conditions needed to embed critical pedagogies into PETE courses and PETE programmes.
\end{abstract}

Palavras chave: Pedagogia crítica. Educação Física. Formação de professores.

Resumo: Estudo sociocrítico e pedagogia crítica, nas últimas três décadas, são centrais na formação de professores de Educação Física. $O$ objetivo deste artigo é providenciar um retrato da história do projeto crítico na formação de professores de Educação Física e oferecer uma análise das pedagogias críticas na sociedade ocidental contemporânea. Nesse texto, as representações de pedagogia crítica são classificadas nos focos sobre (a) reflexão crítica, (b) pedagogias do "desconforto", (c) princípios democráticos, embora os autores reconheçam que na formação de professores tais categorias sobrepõem-se e não são independentes entre si. $O$ artigo conclui que as relações entre professores e alunos na formação inicial em Educação Física são construídas com base na confiança, no cuidado e, secundariamente, que conexões entre professores que atuam na formação superior e a comunidade mais ampla que ensina Educação Física são importantes para providenciar as condições necessárias para as pedagogias críticas nos cursos e programas que formam professores.

Palabras clave: Pedagogía crítica. Educación Física. Formación de profesores.
Resumen: Estudio sociocrítico y pedagogía crítica, en las últimas tres décadas, son centrales en la formación de profesores de Educación Física. El objetivo de este artículo es presentar un retrato de la historia del proyecto crítico en la formación de profesores de Educación Física y ofrecer un análisis de las pedagogías críticas en la sociedad occidental contemporánea. La extensión de esa representación sugiere que los estudios sociocríticos y la pedagogía crítica continúan prosperando en los programas de formación de profesores en varios países. El artículo concluye que las relaciones entre profesores y alumnos de la formación inicial en Educación Física son construidas con base en el cuidado, en la confianza y, secundariamente, que conexiones entre profesores que actúan en la formación superior y la comunidad más amplia que enseña Educación Física son importantes para proporcionar las condiciones necesarias para las pedagogías críticas en los cursos y programas que forman profesores.
*University of Auckland. Auckland, Nova Zelândia.

E-mail: r.philpot@auckland.ac.nz; wayne.smith@auckland.ac.nz; a.ovens@auckland.ac.nz

Received 20 March 2019 Accepted 18 September 2019 Published 15 November 2019

DOl: https://doi.org/10.22456/1982-8918.95142 (c) (i) () Licence 


\section{INTRODUCTION}

Socially-critical scholarship and critical pedagogy have become increasingly more central to PETE over the last three decades. Socially-critical scholarship and advocacy for critical pedagogy in $\mathrm{PETE}$ is now common practice in many countries including the United States (LYNCH; CURTNER-SMITH, 2019), Canada (ROBINSON; RANDALL, 2016), Brazil (ALMEIDA; BRACHT; VAZ, 2015), United Kingdom (FLINTOFF, 2014), Australia (SHELLEY; MCCUAIG, 2018); New Zealand (PHILPOT, 2016a), Sweden (LARSSON; LINNER; SCHENKER, 2018), and Norway (MOEN et al., 2018). The broad aim of socially-critical scholarship as it relates to education and by association PETE, is to understand the socially constructed nature of society and schooling, challenge how and what is being learnt, and become empowered to transform educational practices in the interest of justice, equity, democracy, and human freedom. Critical pedagogy stems from critical scholarship and is a pedagogical practice that has a transformative agenda at its heart. However, while critical pedagogy has been an ideologically attractive idea, it has struggled to demonstrate that it is either feasible in pedagogical terms or effective in changing future teacher behaviour in those learning to teach. In this paper, we focus on socially-critical scholarship and critical pedagogies as they relate to Physical Education Teacher Education (PETE) and provide an overview of how different forms of critical pedagogy are being enacted in PETE. The purpose is to provide a snapshot of the history of the critical project in PETE and an analysis of critical pedagogies in contemporary educational practice.

\section{WHAT IS CRITICAL PEDAGOGY}

The term 'Critical Pedagogy' was originally introduced by the Brazilian educator Paulo Freire to denote an educational philosophy that is grounded in neo-Marxist critical theory (MCLAREN, 2000). However, in more recent times, critical theory has come to refer to a broad spectrum of socio-political theories, including various strands of classical Marxism, postmodernism, and post-colonialism, in addition to neo-Marxism (MCLAREN, 1994; POPKEWITZ; FENDLER, 1999). In general, the common theme among these theories is an emphasis on the political character of education as it relates to issues of equity, democracy and social justice (BELL, 2007). The 'critical' in critical pedagogy evokes a complex array of dispositions, values, suspicions, and questions relating to power inequities and how they lead to privilege and marginalisation. When a pedagogy is described as being critical, it generally refers to the cultivation of a consciousness oriented towards problems associated with power, equity and social justice in ways that can lead to advocacy and community action (WRIGHT, 2004).

The neo-Marxist leanings of critical pedagogy are traced back to a small group of academics from the Frankfurt School in Germany in the 1920s who embarked on a critique of the emerging capitalist system using Marxist theories. Although they focused only on the socioeconomic conditions of the time, their critical theorising is today recognised as the genesis for critical critiques of gender inequity, racism, oppression, and disability discrimination that have had a tremendous transformative effect on society through the 1960s and 70s (DARDER, 2005). More recently, new theoretical frameworks, such as postcolonial, queer and feminist theories have emerged and expanded the field of critical studies and contribute to a broader set of practices collectively identified as critical pedagogy (CARR; KEMMIS, 1986). While the 
context and the nature of the oppressed groups may differ from those who are marginalised by capitalism, the unifying feature of all critical theories is the goal of human emancipation.

\section{PETE AND CRITICAL PEDAGOGY}

Critical pedagogies began to emerge in the field of physical education in the mid-1980s building on the rapid rise of critical social science in education during the 1970s. Scholarship, such as Kirk (1986), Bain (1989), Tinning (1988), Gore (1990) and Fernandez- Balboa (1995) began to question whose interests were being served by particular curriculum and pedagogical arrangements and argue for the introduction of both critical critique and critical pedagogies. In particular, the work of David Kirk and Richard Tinning established the formally little-known Deakin University in Australia as the home of this new form of theorising in the PETE field. The key issues orienting this critical scholarship included questions about the nature of knowledge in PE, specifically the predominance of the human movement sciences; the nature and scope of HPE curricula; the power relationships that influenced our understanding about the body, and issues relating to gender identity, meritocracy, 'technocentric ideology" (BAIN, 1990), obesity (KIRK, 2006), ethics (SICILIA-CAMACHO; FERNÁNDEZ-BALBOA, 2009), and the privileging of certain forms of knowledge (TINNING, 2004).

With respect to PETE in particular, Kirk (1986) advocated for programmes to adopt practices that required PETE students to examine some of the political, social, and ethical dimensions of teaching. Subsequent scholarship advocated for educating pre-service teachers (PSTs) about social justice and equality (e.g., EVANS, 1990; FERNÁNDEZ-BALBOA, 1995), described strategies that had a critical orientation, such as the questioning of taken-for-granted aspects of teaching (GORE, 1990; KIRK, 1986; TINNING, 2002), recognising issues of privilege and oppression in PE and sport (FERNANDEZ-BALBOA, 1995; HICKEY, 2001), linking courses to broader social issues, and inwardly focussing on experience and action research (KIRK, 1986). A smaller but limited quantum of scholarship at this time also explored how critical pedagogies were enacted in PETE (e.g., CURTNER-SMITH, 2004; GORE, 1990; HICKEY, 2001; MACDONALD; KIRK, 1999).

While advocacy for a critical orientation in PETE has been active, a growing body of research has highlighted a number of challenges for teacher educators in respect to the impact and outcomes of critical pedagogy on student teachers. These include the difficulties PETE educators face when critically deconstructing the powerful influence of the student teachers' previous experiences in sport and physical education (BROWN, 1999; GARRETT; WRENCH, 2011; TINNING, 2012); the misalignment between the politics inherent in critical pedagogy and the politics orienting student subjectivity (OVENS, 2017b); the difficulty of changing students' practices through a single course (HICKEY, 2001) and the lack of concrete examples of critical praxis that are required to ensure that $P E$ teachers don't revert back to transmission pedagogies that they themselves experienced in PE (MUROS RUIZ; FERNÁNDEZ-BALBOA, 2005). In addition, Muros Ruiz and Fernández-Balboa (2005) and Ovens, (2017a) suggested that PETE educators' themselves need to turn inward to examine their own subjectivities.

Following two decades of addressing critical theorising and critical pedagogy, as it relates to PETE, Tinning (2002) acknowledged the challenges PETE educators were facing and the limited influence of the enlightenment agenda inherent in critical pedagogy. In response, he 
proposed a 'modest pedagogy' that was less oriented around the radical ideals of enlightenment, empowerment and emancipation, and instead more oriented around problematising knowledge, schooling and students' freedom to participate in contemporary movement culture. Our interpretation of a 'modest pedagogy' or 'modest critical pedagogy' recognises both the importance and difficulty in enacting critical praxis in a post-millennial world. This is characterised as a world of increasing economic disparity, increasingly multicultural societies, and emerging nationalism that appears to be growing in parallel with increased immigration, which is being blamed for changing societies. This links to what Tinning is suggesting in that a critical praxis must be strategic and purposeful yet accept that it is unlikely to be transformative or make a uniform difference to all PETE students.

\section{SOCIALLY-CRITICAL SCHOLARSHIP}

Critical scholarship today continues to highlight inequities in society and education, but it is important to recognise the distinction between critical scholarship and critical pedagogy. Recently, Kirk (2020) drew a distinction between socially-critical scholarship and critical pedagogy, describing socially-critical scholarship as "concerned primarily with analyzing and troubling the normative order of physical education" (p. 93) whereas critical pedagogy is concerned with aligning curriculum, teaching and learning to take action to address injustices.

Socially-critical scholarship as it relates to PE and PETE, is concerned with critiquing social issues specific to physical education. The importance of socially-critical scholarship lies in identifying and naming the injustices so that action can be taken to create change (FREIRE, 1970). The distinction between socially-critical scholarship and critical pedagogy can, however, become blurred when socially-critical scholarship is used to advance issues of social justice rather than simply being "a topic of discussion" (FYALL, 2017, p. 223). For example, Bain's (1975) critique of the hidden curriculum in PE is an example of how socially-critical scholarship can act to draw teachers' attention to the hidden messages in their pedagogy to enable teachers to reflect on and change their practice.

\section{THE NATURE OF PETE CRITICAL PEDAGOGIES}

We now turn our attention to thinking about what critical pedagogy looks like in PETE. This is not easy because how critical pedagogy becomes enacted as a set of practices may be highly variable and situationally dependent. The spectrum tends to range from student centred inquiry with a focus on democratic principles through those that seek to give students' voice, to those that are "pedagogies of discomfort" (SHELLEY; MCCUAIG, 2018, p. 517) where students are confronted with tasks or problems designed explicitly to trouble, disturb and unsettle them.

In what follows we have categorised PETE critical pedagogy under three headings; critical reflection, pedagogies of discomfort; and democratic pedagogies. This categorising builds on other recent attempts to summarise accounts of critical pedagogies in PE/PETE (see for example OVENS, 2017a; PHILPOT, 2015). However, we point out that although categories provide a useful heuristic for our purposes here, in PETE practice these categories do not represent exclusively independent pedagogies but overlap and interconnect. 


\subsection{CRITICAL REFLECTION}

Critical reflection has always been an underpinning element of critical pedagogy that, when enacted in PETE, has invariably proven to be a challenge for PETE students (see DEVISDEVIS; SPARKES, 1999; GORE, 1990). Those who advocate for critical reflection aim to move beyond what Freire (1970) called 'banking' education where students store knowledge unproblematically to focus on exploring issues of context, positionality or power. In the last decade a number of PETE researchers have reported on strategies they have used to stimulate critical reflection. Some of these are explained below.

Visual methodologies, such as photographic essays or diaries, have been one method successfully used to evoke deeper reflection in PETE students. For example, Fitzpatrick and Enright (2017) described how they used a visual diary task to assist students to reflect on gender and identity by engaging in tasks that included observations from PE, TV, sporting events, and sport media. Each task focused the students' attention on PE as a site of gendered practice. Such practices enabled students to "see things they hadn't noticed before" (p. 326). In a similar way, Oliver and Kirk (2017) used visual methodologies such as the examination of magazines, photographic essays, drawings, and scrapbooking to challenge body culture in PE.

A second approach has involved narrative inquiry. Narrative inquiry involving storytelling in PETE invites students to "reflect upon the constitution of their own subjectivities" (DOWLING et al, 2015, p. 936) as a means of influencing their identities as teachers (GARRETT; WRENCH, 2011). McMahon and Penney (2013) used a 13-week block of teaching a group of 79 preservice teachers in an Australian PETE course in a Bachelor of Education (primary) to combine oral storytelling of practicing HPE teachers, written narratives, blogs, and the use of images and drawings. The authors contend that this process of self-discovery and knowing created new insights into understanding their own bodies and how this could provide a foundation for thinking differently about how HPE could be taught.

An important aspect to critical reflection is the way such introspection enables transformative action to occur. As Fitzpatrick and Enright (2017) argue, attention must be paid to ensuring the conditions are in place to support such transformation. These conditions include building relationships, engaging with the politics of young people, valuing student voice by including student voice through discussion and debate, and recognising the relations of power present in any PETE classroom.

\subsection{PEDAGOGIES OF DISCOMFORT}

'Pedagogies of discomfort' is a broad term for a set of teaching strategies that set out to "deliberately trouble, disturb, and unsettle PETE students at a level much deeper than rational cognition" (SHELLEY; MCCUAIG, 2018, p. 517). Biesta (2005) frames this as a pedagogy that "doesn't leave individuals alone, in that it asks difficult questions and creates difficult situations" ( $p$. 63). The common theme of any strategies designed to unsettle and create discomfort is their focus on embodiment and the way embodied experiences enable students to confront their beliefs and values. Embodiment dismisses the distinction between body and mind and positions knowing as embedded through bodily experiences (LISAHUNTER; EMERALD, 2016). Implicit in pedagogies of discomfort are attempts to engage with the affective rather than cognitive domain (TINNING, 
2002), which can often result in frustration, anger and confusion. These strategies have been used in a variety of contexts such as, classrooms (ROSS, 2010), dance/creative movement studios (GARD, 2003; LEGGE, 2011; SHELLEY; MCCUAIG, 2018), service-learning settings (BRUCE, 2015), and education outside the classroom (EOTC) environments (LEGGE, 2010).

One example of a pedagogy of discomfort is Shelley and McCuaig's, (2018) use of embodied experiences in a PETE course to help students focus on unpacking their biographies in terms of the significance and role of cultural heritage and privilege. The suite of pedagogic strategies in the course included a combination of traditional didactic lessons, student-focused inquiry-based approaches, reflection tasks and more radical pedagogies such as dance rehearsals in full body lycra, dressing as the opposite sex and engaging students in arts-based assessment tasks. The authors contend that these pedagogical approaches were intentionally designed to "[...] target the value and belief systems underpinning [white] privilege" (p.519). The course also set students the challenge of choreographing and performing a dance while performing as a gender that is not their own. The authors contend that the course was somewhat successful in helping students to acknowledge their privilege, yet the students were unwilling or unable to explore the implications these new understandings might have for their future teaching.

Similarly, Legge (2011) required her PETE students to publicly perform two movement compositions; one that incorporated contemporary expressive movement and a second that incorporated indigenous Maori movement. In contrast to reflecting on white privilege as in the previous example, Legge (2011) described how the course work served to validate Maori knowledge and identity, saying that:

Te ao kori expressive movement [Māori movement] in the context of mainstream tertiary physical education served as a site for the construction and dissemination of Māori cultural knowledge. To be Māori was seen as normal because Māori cultural aspirations were recognised as valid and authentic (LEGGE, 2011, p. 90).

Legge (2010) also employed a week long experience in a Māori community where a class of predominantly European students learned Maori language, values, beliefs and customs, in a course that was explicitly designed to "stir them (the students) up, get them thinking and see the world from a different perspective" (p. 9). In an auto-ethnographic account of her own teaching in this course, Legge reported that when students were confronted with having to recognise their dominant Pākehā (Eurocentric) hegemonic views of the world, many began to feel frustrated, blamed, or guilty as they became aware that what they knew about Māori people and Māori culture was biased and stereotyped. In addition, Legge (2010) suggested that Māori students experienced similar emotions as they recognised the loss of their own culture and heritage. Legge concluded that the experience caused a bumpy ride due to the students' misunderstandings and misconceptions of Māori history, colonisation and cultural identity.

In contrast to pedagogies explicitly designed to expose privilege and inequity, Clark (2019) described how a PETE educator in an historically black college/university in the USA made efforts to teach in ways that affirm the culture of black students, through culturally responsive teaching and "hard caring" (p. 162). Hard caring in this context consisted of a pedagogy of care for individual wellbeing but also a focus on individual academic success communicated through high expectations of attendance and professionalism, role modelling of these expectations, and a requirement for service to the local community. 
The difficulty and uncertainty of enacting a pedagogy of discomfort was also captured by Bruce (2015) who carried out a self-study of her teaching of a service-learning course. In this course students were required to spend time in a range of community contexts, "getting to know someone or a group of people who come from radically different cultural backgrounds from their own" (p. 237). This included young people who had been excluded from secondary school and disabled youth and young people who were from refugee or migrant backgrounds. While this task appeared potentially enlightening for the students, Bruce experienced resistance. In her journal Bruce writes:

I find myself thinking how deeply the students feel; how angry they seem; how quick they are to judge. And how is it after four years of study these entrenched views run so deep? What is it that can really bring about interruptions ... ruptures ... to this prejudice? (BRUCE, 2015, p. 240)

A later reflection captures the dissonance such pedagogies cause for PETEs trying to challenge taken-for granted perspectives. Bruce (2015, p.241) writes, "[...] challenging questions swirled around in my head. Was I asking too much of the students? Would this experience only serve to increase trauma and epistemic violence towards the Other?" Optimistically, Bruce (2015) proposed that the course did serve to enable students to uncover their prejudices and assumptions, although she concluded that there is no evidence to suggest that the course had any lasting impact.

Philpot, (2017) also described how a lecturer (Tom) who espoused the use of a Freirean pedagogy, had purposefully agitated and 'fired up' PETE students by suggesting that sport was oppressive, that PE teachers should be below other teachers, and by alternating between yelling and long awkward pauses in his lessons. The PETE students reported that at the beginning of their four-year degree they wondered why Tom was teaching in a PE programme as he seemed to have little good to say about PE, but by the end of their degree his approach made sense to them. Ironically, this approach could be construed as inconsistent with Freire's (1970) descriptions of the need for teacher-student relationships that are based on love and humility although Philpot (2017) suggested that Tom's pedagogy was, in fact, built on love a for, and a belief in, the value of equitable physical education.

\subsection{DEMOCRATIC PEDAGOGIES}

Democratic classrooms where teachers and students are equal partners and coinvestigators as a community of learners (FERNÁNDEZ-BALBOA, 1995; FREIRE, 1970) is another condition for enacting critical pedagogy. Democratic classrooms can employ assessment practices that are designed to address hierarchical differences in power by assessing through dialogue, mutual respect and shared decision making. Lorente and Kirk (2013) reported on democratic assessment practices in a course taught by the first author. Lorente empowered the students to make choices both in regard to assessment criteria and self or peer assessment. The authors were conscious that it was necessary for their own assessment practices to model democratic assessment in the PETE course if their desire was for their students to undertake assessment based on democratic principles in their own practice. Lorente and Kirk (2013) concluded that although democratic assessment is often new, uncomfortable and creates anxiety for some students in their own classes, it is time well 
spent as the experiences with democratic assessment are necessary to give teachers the confidence and knowledge to apply these practices in their own work.

Ovens (2017b) also reported how he attempted to infuse democratic principles into a fourth year PETE course. His students were invited to contribute to course design by identifying the learning that was important to their professional learning as teachers. Assessment for the course involved negotiated grading contracts that were marked by student panels and moderated by the lecturer. The students recognised how the course was a departure from their previous experiences of learning and assessment and struggled to be comfortable with the democratic agency involved in enabling them to codesign the course based on their own learning needs. Both Ovens and the students recognised the challenge of applying democratic principles in a course when the students' prior experiences have normalised being complaint. It is clear from both Ovens (2017b) and Lorente and Kirk (2013) that more exposure to democratic pedagogy is necessary if students are to benefit from a less hierarchical relationship in PETE.

Kim Oliver and her colleagues at New Mexico State University, USA have reported on class practices designed to enact the principles of democracy in school physical education. Oliver's research (OLIVER; OESTERREICH, 2013) involved interventions in school-based methods courses designed to help pre-service teachers learn how to do student-centred and inquiry-based teaching with high school students in PE. Oliver and Oesterreich (2013) reported how the PETE students gave voice to the school students by actively listening and taking action on the student perspectives such as identifying and analysing barriers to adolescents' physical activity and implementing alternative types of activity. The authors concluded that "teacher educators must be willing to take risks and work beyond their pretexts of what teacher education has been - learning at the university and enacting it in the schools" (p. 414).

More recently, Oliver and Kirk (2015) reported on a second PETE school-based course that employed a student-centred inquiry as a pedagogy to stimulate critical reflection. Based on learning to value democratic principles, the PETE student-participants were required to negotiate student-voice in the curriculum planning. This required the PETE students to interview school students about their perceptions of PE and where they wanted to focus their learning. From this the PETE students were required to develop five lessons that explicitly showed how student voice was incorporated in the planning. They reported that listening to student voices resulted in a wider range of activities that motivated students to participate and accept challenge in a safeto-fail environment characterised by stronger relationships. The authors suggest that although there was some evidence of girls identifying and naming barriers to their participation in regular physical activity there was little evidence that pupils were able to critique these barriers and find ways to overcome or transform them.

\section{DISCUSSION}

In this paper, we have provided recent accounts of critical pedagogy that have been enacted in PETE. The first message for PETE educators is to be true to Freire's (1970) call to avoid a conception of critical pedagogy as a single decontextualised method. In our overview we have shown examples that are situated in specific PETE programmes. The reader should recognise that the pedagogy may require revision if used in different contexts. The message is that critical PETE educators must remain conscious and reflexive about the context they work 
in (PETE) and equally, to recognise the context they may not be strongly connected to (school physical education). Pink (2011, cited in LISAHUNTER; EMERALD, 2016) used the concept of 'emplacement' to signify the importance of situating practice within a context. Emplacement refers to a "unique environment in progress" (p. 344). Embodied experiences are therefore contextually embodied experiences that cannot be transported unproblematically from the context of PETE to and into schools.

A second consistent theme that emerges from these PETE critical pedagogies is the call for building trusting relationships as a pre-cursor for pedagogical engagement. For example, Legge (2011) emphasised the importance of developing an environment of trust, autonomy and student empowerment when enacting traditional Māori movement in a public creative movement performance. She stated that when students take ownership of the creative process, they "[...] develop interpersonal relationships built on trust, support, comradeship and confidence in each other [...]" (p. 91). Similarly, Dowling, Garrett, lisahunter, and Wrench, (2015) stressed the importance of building trusting learning relationships, respecting confidentiality and recognising power relations, while Clark (2019) showed how a teacher educator developed an environment of care as a part of addressing social justice issues.

The difficulty of deconstructing preexisting student beliefs and dispositions is a third commonly reported message. The literature shows that any attempt to deconstruct strongly held beliefs requires a PETE to tread a delicate balance if they wish to avoid an emotional fallout. In the current neoliberal university where student voice is used as a message of course success, pedagogies of discomfort are not without their tensions. As Kenway and Bullen (2002) argued, 'students do not tend to appreciate teachers [or professors] who make them feel ashamed about their choices and lifestyles - all in the name of helping them' (p. 156) while Shelley and McCuaig (2018) acknowledged this tension stating that:

\footnotetext{
[...] being aware of the need to push students to this point of dissonance is to walk a paradigmatic and pedagogical tightrope: push too far and students disavow both the message and the messenger, failure to push far enough results in the acceptance and perpetuation of existing beliefs and business as usual...pushing too far can also result in students feeling overwhelmed and impotent, unwilling to address inequity because problems seem insurmountable and out of their immediate control (SHELLEY; MCCUAIG, 2018, p.520).
}

Enacting democratic principles in one's own PETE classes is a further message from the literature, for example, both Ovens (2017b) and Lorente and Kirk (2013) provide insight into the use of democratic assessment. They stressed the value of negotiating course work and assessment before courses begin; the need to scaffold students from peer to self-assessment; the importance of assessment criteria that provides clarity about assessment; and finally; the nurturing required to give students the confidence and ability to genuinely negotiate, to choose both if and how assessment will be used.

PETE educators should also acknowledge the challenge for new physical education (PE) teachers to introduce critical pedagogy in schools. Gerdin, Philpot and Smith (2018) for example, have reported that difficulties new PE teachers face when they begin their teaching roles. Oliver et al. (OLIVER et al., 2015; OLIVER; KIRK, 2015; OLIVER; OESTERREICH, 2013) have aimed to bridge this gap by placing PETE in methods courses in schools where PETE students can experience and engage in critical pedagogy within their PETE field experience courses. These attempts to connect PETE to school PE may serve to help PETE graduates to 
recognise that the critical pedagogies used in their PETE programme are also pertinent in their teaching roles.

Although the previous accounts are a salient reminder that critical pedagogy is challenging, it may enabled through a supportive policy environment and conducive institutional constraints (OVENS, 2017a, 2019). Ovens suggests that all pedagogy is situated within networks of power relations that simultaneously constrain and enable teaching practices. He states that critical pedagogies are enabled when social justice becomes an underpinning principle of a group rather than just an individual. The implication is that in enacting critical pedagogy, PETE educators should be conscious of how their connections with other PETE educators can create epistemic communities (LAWSON, 2009) or communities of practice that privilege "social-cultural communities of knowledge" (p.99). Similarly, Kirk (2019a) has called for networked learning communities that include all stakeholders and provide support for teacher professional learning that advances critical pedagogy beyond PETE. Connections between PE colleagues who align with critical PE can be strengthened if social justice agendas are recognised. In New Zealand and Australia, critical pedagogies are further enabled through the introduction of socially-critical Health and Physical Education (HPE) curriculum documents (See for example MINISTRY OF EDUCATION, 1999) that endeavour to shift the subject from its historical technical-rational logic to a logic informed by social justice and a socioecological perspective (CULPAN; BRUCE, 2007).

Currently, we lack evidence to show how networked learning communities and aligned policy documents serve to enable PETE critical pedagogies, but the suggestion is that future research should focus on the development of collective, rather than individual agency, and developing strong communities of practice that value diversity and democratic principles.

We recognise that students are unlikely to adopt critical pedagogies without a belief in their value (GORE, 1990), or put another way, PETE students are most likely to practice in ways that are consistent with their own beliefs. The critical pedagogies reported in this paper represent diverse attempts that aim to challenge PETE student beliefs and provide experiences of teaching approaches that can be adapted for future PE classroom practices (see for example OLIVER; KIRK, 2015; OLIVER; OESTERREICH, 2013). However modest these aims may be, we are hopeful that the growth of socially-critical scholarship and PETE critical pedagogies will be enabled by emerging networks of PETE teacher educators and PE teachers who share a concern for social justice and feel empowered to act on social inequities.

\section{REFERENCES}

ALMEIDA, Felipe Quintão; BRACHT, Valter; VAZ, Alexandre Fernandez. Educação Física, pedagogia crítica e ideologia: gênese e interpretações. Movimento, v. 21, n. 2, p. 317-331, 2015.

BAIN, Linda. A critical analysis of the hidden curriculum. In: KIRK, David; TINNING, Richard. Physical education, curriculum and culture: Critical issues in the contemporary crisis. London, UK: Falmer, 1990. p. 23-42. 
BELL, Lee Anne. Theoretical foundations for social justice education. In: Teaching for diversity and social justice. London: Routledge, 2007. p. 25-38.

BIESTA, Gert. Against learning. Nordisk pedagogik, v. 25, n. 1, p. 54-66, 2005.

BROWN, David. Complicity and reproduction in teaching physical education. Sport, Education and Society, v. 4, n. 2, p. $143-159,1999$.

BRUCE, Judith. On racism and prejudice: exploring postcritical possibilities for service-learning within physical education teacher education, Asia-Pacific Journal of Health, Sport and Physical Education, v. 6, n. 3, p 233-244, 2015.

CARR, Wilfred; KEMMIS, Stephen. Becoming critical: education, knowledge and action research. Geelong, VIC: Deakin University, 1986.

CLARK, Langston. The Way They Care: An Ethnography of Social Justice Physical Education Teacher. The Teacher Educator, v. 54, n. 2, p. 145-170, 2019.

CULPAN, lan; BRUCE, Judith. New Zealand physical education and critical pedagogy: Refocusing the curriculum. International Journal of Sport and Health Science, v. 5, n. p. 1-11, 2007.

DARDER, Antonia. Schooling and the culture of dominion: Unmasking the ideology of standardized testing. In: FISCHMAN, Gustavo. Critical theories, Radical Pedagogies, and Global Conflicts. Lanyard MA: Rowman \& Littlefield, 2005. p. 207-222.

DOWLING, Fiona; GARRETT, Robyne; HUNTER, Lisa; WRENCH, Alyson. Narrative Inquiry in physical education research: the story so far and its future possibilities. Sport, Education and Society, v. 20, n. 7, p. 924-940, 2015.

ENRIGHT, Eimear et al. "Student Voice as Risky Praxis: democratising Physical Education teacher education." Physical Education and Sport Pedagogy, v. 22, n. 5, p. 459-472, 2017.

EVANS, John. Ability, position and privilege in school physical education. In: Physical education, curriculum and culture: critical issues in the contemporary crisis. KIRK, David; TINNING, Richard. London, UK: Falmer, 1990. p. 139-168.

FERNÁNDEZ-BALBOA, Juan Miguel. Reclaiming physical education in higher education through critical pedagogy. Quest, v. 47, p. $91-114,1995$.

FITZPATRICK, Katie; ENRIGHT, Eimear. Gender sexuality and physical education. In: ENNIS, C. The Routledge Handbook of Physical Education Pedagogies. New York: Taylor and Francis, 2017. p. 319-331.

FLINTOFF, Anne. Tales from the playing field: Black and minority university students' experience of physical education teacher education. Race, Ethnicity and Education, v. 17, n. 3, p. 346366, 2014.

FLINTOFF, Anne; DOWLING, Fiona. 'I just treat them all the same, really': Teachers, whiteness and (anti) racism in physical education. Sport, Education and Society, v. 24, n. 2, p. 121-133, 2019.

FREIRE, Paulo. Pedagogy of the oppressed. New York, NY: Seabury, 1970.

FYALL, Glenn. Graduating physical education student teachers' perceptions of a critically oriented HPE curriculum:(re) constructing constructivist frameworks in PETE. Asia-Pacific Journal of Health, Sport and Physical Education, v. 8, n. 3, p. 211-228, 2017. 
GARRETT, Robyne; WRENCH, Alison. Making physical education a fairer, safer and happier place: Putting critical practices into action. Asia-Pacific Journal of Physical Education, v. 2, n. 2, p. $35-50,2011$.

GIROUX, Henry. Critical theory and educational practice. In: DARDER, Antonia; BALTODANO, Marta; TORRES, Rodolfo. The critical pedagogy reader. New York, NY: Routledge, 2009. p. 27-51.

GERDIN, Göran; PHILPOT, Rod; SMITH, Wayne. It is only an intervention, but it can sow very fertile seeds: graduate physical education teachers' interpretations of critical pedagogy. Sport, Education and Society, v. 23, n. 3, p. 203-215, 2018.

GORE, Jennifer. Pedagogy as text in physical education teacher education: Beyond the preferred reading. In: KIRK, David; TINNING, Richard. Physical education, curriculum and culture: Critical issues in the contemporary crisis. London, UK: Falmer, 1990. p. 101-138.

HICKEY, Chris. I feel enlightened now, but...: The limits to the pedagogical translation of critical discourses in physical education. Journal of Teaching in Physical Education, v. 20, p. 227 246, 2001.

KIRK, David. A critical pedagogy for teacher education: Toward an inquiry-oriented approach. Journal of Teaching in Physical Education, v. 5, p. 230-246, 1986.

KIRK, David. The obesity crisis and school physical education. Sport, Education and Society, v. 1, n. 2, p. $121-133,2006$.

KIRK, David. A new critical pedagogy for physical education in 'turbulent times': What are the possibilities? In. PRINGLE, Richard; LARSSON, Hakkan; GERDIN, Göran. Critical Research in sport, health and Physical Education. London: Routledge 2019a. p. 106-118.

KIRK, David. Precarity, critical pedagogy and physical education, London: Routledge, 2020.

LARSSON, Lena; LINNER, Sussane; SCHENKER, Katarina. The doxa of physical education teacher education - set in stone. European Physical Education Review, p. 1-22, 2017.

LEGGE, Mareen. "E noho marae - Transforming Learning through Direct Māori Cultural Experience." In: JESSON, Jocelyn et al. University teaching reconsidered: justice, practice, equity. Wellington, NZ: Dunmore, 2010. p. 139-149.

LEGGE, Mareen. Te ao kori as expressive movement in Aotearoa New Zealand Physical Education teacher education (PETE): a narrative account. Asia-Pacific Journal of Health, sport and Physical Education, v. 1, n. 3-4, p. 81-95, 2011.

HUNTER, Lisa; EMERALD, Elke. Sensory narratives: Capturing embodiment in narratives of movement, sport, leisure and health. Sport, Education and Society, v. 21, n. 1, p. 28-46, 2016.

LORENTE, Eloisa; KIRK, David. Alternative democratic assessment in PETE: An action-research study exploring risks, challenges and solutions. Sport, Education and Society, v. 18, n.1, p. 77 - 96, 2013.

LYNCH, Shrehan; CURTNER-SMITH, Matthew. "The education system is broken:" The Influence of a sociocultural foundations class on the perspectives and practices of Physical Education preservice teachers. Journal of Teaching in Physical Education, v. 00, p. 1-11, 2019. (ahead of print) 
MACDONALD, Doune; KIRK, David. Pedagogy, the body and Christian identity. Sport, Education and Society, v. 4, n. 2, p. 131-142, 1999.

MCLAREN, Peter. Life in schools: an introduction to critical pedagogy in the foundations of education. White Plains, NY: Longman, 1994.

MCLAREN, Peter. Paulo Freire's pedagogy of possibility. In: STEINER, Steiner; KRANK, Mark; MCLAREN, Peter; BAHRUTH, Robert. Freirean pedagogy, praxis and possibilities: Projects for the new millennium. New York: Falmer, 2000. p. 1-21.

MCMAHON, Jennifer; PENNEY, Dawn. Using narrative as a tool to locate and challenge preservice teacher bodies in health and physical education. Australian Journal of Teacher Education, v. 38, n. 1, p. 114-133, 2013.

MINISTRY OF EDUCATION NEW ZEALAND. Health and physical education in the New Zealand curriculum. Wellington: Learning Media, 1999.

MOEN, Kjersti; WESTLIE, Knut; SKILLE, Eivind. The changing room in Physical Education as cross roads between fields and curricula: the experiences of norwegian Students. SAGE Open, v. 8, n. 4, 2018. doi/10.1177/2158244018818926.

MUROS RUIZ, Beatriz; FERNÁNDEZ-BALBOA, Juan Miguel. Physical education teacher educators' personal perspectives regarding their practice of critical pedagogy, Journal of Teaching in Physical Education, v. 24, p. 243-264, 2005.

OLIVER, Kimberly; KIRK, David. Girls, gender and Physical Education: an activist approach, London: Routledge, 2015.

OLIVER, Kimberly; KIRK, David. "Challenging body culture in Physical Education." In: ENNIS, Catherine. The Routledge Handbook of Physical Education Pedagogies, New York: Taylor and Francis, 2017. p. 307-318.

OLIVER, Kimberly; OESTERREICH, Heather. "Student-centred Inquiry as Curriculum as a model for field-based teacher Education." Journal of Curriculum Studies, v. 45, n. 3, p. 394-417, 2013.

OLIVER, Kimberly et al. 'The sweetness of struggle': innovation in physical education teacher education through student-centered inquiry as curriculum in a physical education methods course. Physical Education and Sport Pedagogy, v. 20, n. 1, p. 97-115, 2015.

OVENS, Alan. "Transformative aspirations and realities in Physical Education teacher education (PETE)." In: ENNIS, Catherine. The routledge handbook of Physical Education pedagogies. New York: Taylor and Francis, 2017a. p. 295-306.

OVENS, Alan. Putting complexity to work to think differently about transformative pedagogies in teacher education. Issues in Teacher Education, v. 26, n. 3, p. 38-51, 2017b.

OVENS, Alan et al. How PETE comes to matter in the performance of social justice education, Physical Education and Sport Pedagogy, v. 23, n. 5, p. 484-496, 2018.

OVENS, Alan; LYNCH, Shrehan. Democratic teacher education practices. In: PETERS, Michael. Encyclopedia of Teacher Education. Singapore: Springer, 2019. p. 1-6.

PHILPOT, Rod A. Critical Pedagogies in PETE: An Antipodean Perspective. Journal of Teaching in Physical Education, v. 34, n. 2, p. 316-332. doi: 10.1123/itpe.2014-0054, 2015. 
PHILPOT, Rod A. Shaking Student's Cages: A Freirean Pedagogy that Challenged PETE Students' Beliefs About Physical Education. International Journal of Critical Pedagogy, v. 7 , n. 1, p. 143-164, $2016 \mathrm{a}$.

PHILPOT, Rod A. Physical Education Initial Teacher Educators Expressions of Critical Pedagogy(ies): coherency, complexity or confusion? European Physical Education Review, v. 22, n. 2, p. 260-275, 2016b.

PLUIM, Carolyn; GARD, Michael. Physical education's grand convergence: Fitnessgram®, bigdata and the digital commerce of children's health. Critical studies in education, v. 59, no. 3, p. 261-278, 2018.

POPKEWITZ, Thomas; FENDLER, Lynn. Critical theories in education: changing terrains of knowledge and politics. New York: Routledge, 1999.

ROBINSON, Daniel; RANDALL, Lynn. An Introduction. In: ROBINSON, Daniel; RANDALL, Lynn. Social justice in Physical Education: critical reflections and Pedagogies for Change. Toronto: Canadian Scholars', 2016. p 1-14.

SHELLEY, Karen; MCCUAIG, Louse. Close encounters with critical pedagogy in socio-critically informed health education teacher education, Physical Education and Sport Pedagogy, v. 23, n. 5, p. 510-523, 2018.

SCHENKER, Katarina et al. Conceptualising social justice - what constitutes pedagogies for social justice in HPE across different contexts?, Curriculum Studies in Health and Physical Education, v. 10, n. 2, p. 126-140, 2019.DOI: 10.1080/25742981.2019.1609369.

SICILIA-CAMACHO, Alvaro; FERNÁNDEZ-BALBOA, Juan Miguel. Reflecting on the moral bases of critical pedagogy in PETE: toward a foucaultian perspective on ethics and the care of the self. Sport, Education and Society, v. 14, n. 4, p. 443-463, 2009.

TINNING, Richard. Student teaching and the pedagogy of necessity. Journal of teaching in physical education, v. 7, n. 2, p. 82-89, 1988.

TINNING, Richard. Toward a "modest pedagogy": Reflections on the problematics of critical pedagogy. Quest, v. 54, n.3, p. 224-240, 2002.

TINNING, Richard. Rethinking the preparation of HPE teachers: Ruminations on knowledge, identity, and ways of thinking. Asia-Pacific Journal of Teacher Education v. 32, n. 3, p. 241253, 2004.

TINNING, Richard. A socially-critical HPE (aka physical education) and the challenge for teacher education. In: DOWN, Barry; SMYTH, John. Critical voices in teacher education: Teaching for social justice in conservative times. Dordrecht: Springer, 2012. p. 223-238.

TINNING, Richard. Critical pedagogy in physical education as advocacy and action: A reflective account. In: PRINGLE, Richard; LARSSON, Hakkan; GERDIN, Göran. Critical research in sport, health and physical education: How to make a difference. London: Routledge, 2019. p. 93-105.

WRIGHT, Jan. Critical inquiry and problem-solving in physical education. In: WRIGHT, Jan; MACDONALD, Doune; BURROWS, Lisette. Critical inquiry and problem-solving in physical education. London: Routledge, 2004. p. 1-16. 